
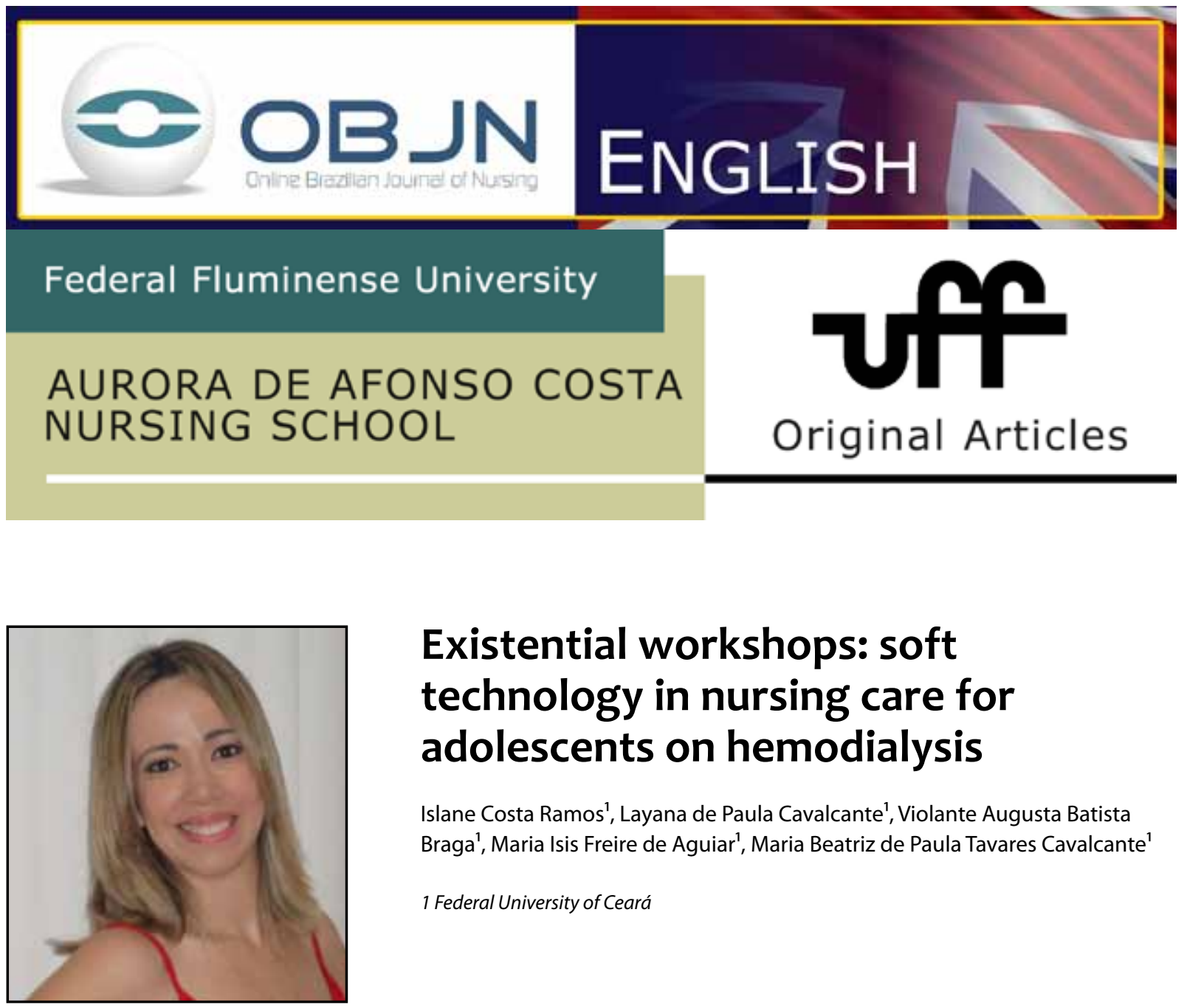

\title{
Existential workshops: soft technology in nursing care for adolescents on hemodialysis
}

\author{
Islane Costa Ramos ${ }^{1}$, Layana de Paula Cavalcante' ${ }^{1}$, Violante Augusta Batista \\ Braga', Maria Isis Freire de Aguiar', Maria Beatriz de Paula Tavares Cavalcante ${ }^{1}$ \\ 1 Federal University of Ceará
}

\section{ABSTRACT}

Aim: To describe and evaluate the use of soft technology in nursing care for adolescents suffering from chronic renal diseases and undergoing hemodialysis. Method: This is a convergent-care study, using a qualitative approach, performed in a dialysis clinic in Fortaleza/CE between February and April 2012. Eight workshops were conducted, with the participation of eight teenagers. For the analysis of the information we used a structuring process, which includes collection, synthesis, theorization and contextualization. Results: The technology allowed the expression of feelings, the observation of behavioral changes and the identification of emotional responses, associated with the experiences of chronic renal patients undergoing hemodialysis. Discussion: It reinforces the importance of soft technology use in this scenario, since the creation of a therapeutic environment and the doctor-patient interaction favor an individualized and humanized care. Conclusion: The technology favored humanization and working on aspects related to hosting, sharing experiences, sensitive listening and the development of a bond.

Descriptors: Adolescents; Renal Dialysis; Nursing Care. 


\section{INTRODUCTION}

Chronic kidney disease is a condition that causes various demands on the patient, because it jeopardizes the physical and psychological aspects and has personal, family and social impacts $^{(1)}$. An integral and humanized care by health professionals that meets these demands, specifically for teenagers inserted into dialysis treatment, is necessary on a daily basis.

The disease results from the progressive, irreversible and generally slow loss of renal function, which leads patients to undergo replacement therapies. This is a serious public health problem, because the prevalence of people in dialysis programs has increased significantly in recent years, and the tendency is for this to rise even further. In Brazil, approximately 21,000 patients a year need to undergo renal replacement therapy, which may occur by means of hemodialysis or peritoneal dialysis ${ }^{(2,3)}$.

In adolescence, body change is very important, not only in terms of physiology, but also in relation to what it now represents in the eyes of society ${ }^{(4)}$.

In addition to the biological and subjective changes that generate conflicts, this phase can be even more difficult if a disease such as chronic renal failure (CRF), which results in many restrictions and changes in lifestyle, as a result of the disease and its treatment, is added to the equation ${ }^{(2)}$.

In practice, it is observed that people in this age group complain about the disease as something that disrupts their lives, often resulting in maladjustments in their personal and family life. In addition to the reported physical damage, losses related to social and psychological aspects, which should be valued, are also referred to ${ }^{(5)}$.

Advancements in the scientific process of diagnosis and therapy are factors that have contributed to changes in the health care pa- radigm - previously focused on the treatment of severe acute diseases, it is now also aimed at care, seeking the best prognosis and quality of life for individuals with chronic diseases ${ }^{(1,6)}$.

Traditionally, care services for people who suffer from chronic diseases are developed through a routine that begins with the diagnosis, the definition of a treatment and monitoring to evaluate whether any adjustments are necessary. This model of care also needs to appreciate and address what it means to each individual having such a pathological condition ${ }^{(1)}$. The meaning that each individual attributes to it requires the use of new care technologies, making the insertion of soft technologies necessary, in a context dominated by hard and soft-hard technology.

Technologies are classified as soft when it comes to relationships and hosting; as soft-hard when we refer to structured knowledge, as in the nursing process; and hard when they involve technological equipment and standards $s^{(7)}$.

The idea of technology should not only be linked to equipment (a fact quite evident when it comes to CRF, in which the approach is mainly directed to the use of "hard" technology (dialysis machines, standards and generalized routines)), since aspects such as the production of shared knowledge, the shared responsibility of people in relation to care, the emotional approach, hosting, a more comprehensive professional involvement and an individualized, holistic and humanized perception of these people.

In the health field, although technology categories are interrelated, the logic of the work that is expressed in terms of the equipment and structured knowledge should not prevail; rather, human beings need relationship technologies, production of knowledge, communication, hosting, bonds and empowerment, which are known as "soft technologies"(8).

Based on the above, it is considered that the use of soft technology in nursing care aimed 
at adolescents on hemodialysis may favor humanization, because it includes aspects related to bonding, comforting and self-expression. From the moment teenagers suffering from CRF have the opportunity to express their problems, conflicts, emotions and expectations through this technique (represented by experiential workshops and expressive techniques), it is considered that they will be better able to deal with the demands associated with being chronic renal patients, while going through their teenage years, which is an important development phase.

In this context, this study is relevant in regard to contributing to measures that result in humanization, and thus may favor physical and mental health and promote the quality of life of these adolescents. Therefore, the objective of this study is to describe the experiential workshops as soft technology and evaluate the use of this technique in nursing care aimed at adolescents with chronic renal failure undergoing hemodialysis.

\section{METHOD}

This is a convergent-care study, using a qualitative approach. It was performed in a dialysis clinic contracted by the Unified Health System (SUS), which is a reference in the care of adolescents with CRF problems, located in the city of Fortaleza/CE, from February to April 2012.

The participants were eight teenagers diagnosed with CRF and undergoing dialysis. The inclusion criteria: to be included in the age group of adolescents defined by the World Health Organization, that is, 10-19 years old; to undergo hemodialysis treatment for over six months (so that they could experience the dialysis process, which would allow a better analysis); to be part of the dialysis shift with the largest number of adolescents; and to accept and be authorized by their parents or guardians to participate in the study.

We intentionally chose the group that underwent dialysis treatment on Mondays, Wednesdays and Fridays in the 2nd shift, since this was the period with the largest concentration of adolescents.

The meetings were scheduled to start one hour after the beginning of the dialysis session, so they were also finalized before the end of hemodialysis. The chosen time for the workshops took into account the physiological and behavioral changes or specific complications of the dialysis process, which could interfere with or preclude the development of activities.

Each of the eight weekly meetings occurred over two months. The workshop was divided into three distinct phases, corresponding to the beginning, middle and end: heating technique (beginning); development (presentation of the theme by the moderator, individual construction and socialization with the group); and evaluation $^{(9)}$. An individual diary (index) was designed so that every teenager could register how they were feeling at the beginning and end. At the end of each meeting, suggestions for topics for the next meeting were requested from the adolescents and the one that was considered of greatest interest to the group was chosen.

In convergent-care research, the subject must come from the study participants and from their everyday life. Thus, this theme will be associated with the situation of practice and it shall be chosen from problems experienced by the people who are active in the situation ${ }^{(10)}$.

To perform the work carried out in the workshops, various types of materials and strategies were available, which favor the expression of thoughts and feelings of the adolescents related to their experiences of having chronic renal failure. As a methodological strategy for the work carried out in the workshops, we used 
graphic or imaginary representations by means of drawings produced by individuals, games for idea association and songs and tales. Manifestations (behavior, participation, interaction) were recorded in the field diary and individual binder, with the collaboration of another observer of the workshops.

For the analysis of the information collected, we used Morse and Field's structuring process, presented by Trentini and Paim(10): "in any kind of qualitative research, analyzing the information consists of four generic processes: collection, synthesis, theorization and contextualization, which occur more or less in a sequence."

The research project was submitted for consideration by the Ethics Committee in Research at the Federal University of Ceará, and was approved according to Opinion No. 226/11.

In accordance with Resolution 466/12 of the National Health Council ${ }^{(11)}$, teens who signed the Consent Agreement, which informed them of the research objectives and assured them anonymity, were included in the investigation. The Informed Consent Form (ICF) was signed by parents or legal guardians.

\section{RESULTS}

Figure 1 shows the synthesis of the proposed soft technology development process in nursing care, describing the group techniques and strategies used in its implementation in the daily care aimed at adolescents suffering from chronic renal diseases on hemodialysis, who are the subjects of this study.

The development technique initially proposed was the catalog, which aimed to meet/ approach the group, and it was performed as planned. In this first meeting, it was noted that adolescents participated actively and liked to express themselves verbally, despite having difficulty in speaking to the group, as this was not a common practice among them. It was possible to perceive that they valued their families and liked fun things, but they also felt different because of CRF and lived with economic and social difficulties (in their justifications, they reported facts related to interfamily violence and financial difficulties).

The technique known as the present was used in workshop 2. In this technique, we asked the teens to do a graphic representation of what they would like to win, what they wanted to give as a gift and to whom. Most participants mentioned material things they wanted to win, such as a house, a car, clothes, makeup, shoes, a computer, a television set and toys. However, they also cited health, a transplant, an arteriovenous fistula, affection and going back to school. As to whom they would like to give a gift: five teenagers said their mother; one teenager said their grandmother; one teenager said her grandfather; and one teenage girl mentioned the nursing technician who took care of her. The drawings depicted material things (home appliances, houses, clothes) or things associated with affection, such as roses and expressions of affection and gratitude (hugging and kissing).

In workshop 3, the magic book technique was developed, which aimed to build up the adolescents' self-esteem and expectations through the life story told by them. As each teenager presented his/her report, the group showed interest and surprise. Each participant told his/her story in a quiet, nostalgic and humorous way. They highlighted good things, but at times, they spoke of the obstacles and difficulties they encountered due to the treatment. The entire group listened with attention and respect.

In workshop 4, the secret friend was the central technique employed, in order to work on aspects related to communication and group 
Figure 1 - Descriptive Synthesis of the process of experiential workshops with adolescents suffering from CRF during hemodialysis. Fortaleza 2012.

\begin{tabular}{|c|c|c|c|c|}
\hline WORKSHOPS & OBJECTIVES & TECHNIQUES & MATERIALS & SUMMARY \\
\hline \multirow{2}{*}{1} & \multirow{2}{*}{$\begin{array}{l}\text { Present / know the } \\
\text { group. }\end{array}$} & $\begin{array}{l}\text { 1-Heating: My clip- } \\
\text { board. }\end{array}$ & \multirow{2}{*}{$\begin{array}{l}\text { Glue, partitioned folder, } \\
\text { cardboard, magazine } \\
\text { clipping, A4 paper and } \\
\text { wood paper. }\end{array}$} & \multirow{2}{*}{$\begin{array}{l}\text { Presentation of the indivi- } \\
\text { dual productions; prepara- } \\
\text { tion of a panel called The } \\
\text { Group. }\end{array}$} \\
\hline & & 2-Theme: The catalog. & & \\
\hline \multirow{2}{*}{2} & \multirow{2}{*}{$\begin{array}{l}\text { Discourse on dreams, } \\
\text { affection and pros- } \\
\text { pects }\end{array}$} & $\begin{array}{l}\text { 1-Heating: Positive } \\
\text { thinking. }\end{array}$ & \multirow{2}{*}{$\begin{array}{l}\text { White paper craft, } \\
\text { colored pencils, colo- } \\
\text { red brushing pens and } \\
\text { crayons. }\end{array}$} & \multirow{2}{*}{$\begin{array}{l}\text { Preparation of drawings to } \\
\text { express what teens would } \\
\text { like to receive and give. }\end{array}$} \\
\hline & & 2-Theme: The present. & & \\
\hline \multirow[b]{2}{*}{3} & \multirow[b]{2}{*}{$\begin{array}{l}\text { Work values, expecta- } \\
\text { tions and self-esteem. }\end{array}$} & 1-Heating: Guess who? & \multirow[b]{2}{*}{ Paper, glue and mirror. } & \multirow{2}{*}{$\begin{array}{l}\text { Teenagers told their story, } \\
\text { which was recorded on a } \\
\text { panel for group knowled- } \\
\text { ge. }\end{array}$} \\
\hline & & 2-Theme: Magic book. & & \\
\hline \multirow[b]{2}{*}{4} & \multirow{2}{*}{$\begin{array}{l}\text { To promote the inte- } \\
\text { gration of the group } \\
\text { and communication. }\end{array}$} & 1-Heating: idea Storm & \multirow{2}{*}{$\begin{array}{l}\text { White paper craft, pens, } \\
\text { colored pencils and } \\
\text { crayons. }\end{array}$} & \multirow{2}{*}{$\begin{array}{l}\text { Discussion on the themes } \\
\text { hosting, interaction, res- } \\
\text { pect and team. }\end{array}$} \\
\hline & & $\begin{array}{l}\text { 2-Theme: Secret } \\
\text { Friend. }\end{array}$ & & \\
\hline \multirow{2}{*}{5} & \multirow{2}{*}{$\begin{array}{l}\text { "Discuss values, fee- } \\
\text { lings and respect for } \\
\text { differences." }\end{array}$} & $\begin{array}{l}\text { 1-Heating: History of } \\
\text { the name }\end{array}$ & \multirow{2}{*}{$\begin{array}{l}\text { White paper craft, pens, } \\
\text { scissors, glue and wood } \\
\text { paper. }\end{array}$} & \multirow{2}{*}{$\begin{array}{l}\text { Presentation of written } \\
\text { productions; preparation } \\
\text { of a panel called The ladder } \\
\text { of the group. }\end{array}$} \\
\hline & & $\begin{array}{l}\text { 2-Theme: The stair- } \\
\text { case. }\end{array}$ & & \\
\hline \multirow{2}{*}{6} & \multirow{2}{*}{$\begin{array}{l}\text { Address on the subject } \\
\text { drug. }\end{array}$} & $\begin{array}{l}\text { 1-Heating: Surprise } \\
\text { Box }\end{array}$ & \multirow{2}{*}{$\begin{array}{l}\text { Shoe box, silk fabric, } \\
\text { small sandpaper, steel } \\
\text { wool, cotton, cold and } \\
\text { warm compress. }\end{array}$} & \multirow{2}{*}{$\begin{array}{l}\text { Expression of the sen- } \\
\text { sations provided by the } \\
\text { applied technique, relating } \\
\text { to the theme drugs. }\end{array}$} \\
\hline & & 2-Theme: The touch. & & \\
\hline 7 & $\begin{array}{l}\text { Encourage verbaliza- } \\
\text { tion and provide for } \\
\text { integration }\end{array}$ & $\begin{array}{l}\text { 1-Heating: The body } \\
\text { speaks } \\
\text { 2-Theme: window of } \\
\text { the soul. }\end{array}$ & $\begin{array}{l}\text { White paper craft, pens, } \\
\text { wooden box and a small } \\
\text { ball. }\end{array}$ & $\begin{array}{l}\text { Group exposure by means } \\
\text { of the worked technique; } \\
\text { evaluation of the meeting. }\end{array}$ \\
\hline 8 & $\begin{array}{l}\text { Assess what has } \\
\text { been worked in the } \\
\text { workshops and what } \\
\text { it represented for } \\
\text { adolescents }\end{array}$ & 1-Heating: Longing. & $\begin{array}{l}\text { White paper craft, pens, } \\
\text { wooden box, picture of a } \\
\text { black and white backpa- } \\
\text { ck, colored pencils and } \\
\text { crayons. }\end{array}$ & $\begin{array}{l}\text { Presentation of the indivi- } \\
\text { dual productions; group } \\
\text { discussion on the panel } \\
\text { built. }\end{array}$ \\
\hline
\end{tabular}

interaction, and thus favor the bond of friendship between the teenagers through graphical representations and exchanges of information. This meeting allowed the discussion of issues, such as hosting, completeness, inclusion and community.

The technique used in workshop 5 was the ladder, in which values and diversity were worked on. It was observed that adolescents were thoughtful/silent, as if they had difficulty or had some doubts in choosing the three issues in descending order, which they considered of greatest value in their lives. As a whole, the group spoke about issues related to family, school and their treatment, verbalizing feelings and valuing affection. A panel with a drawing of a ladder was then presented to the group, which was entitled "Group ladder". The teenagers put what they had written on their ladder, and in the same sequence, on the panel, with the help of engineers and professionals. At the end, we asked them to talk about the differences and similarities between their ladders. It was noticed that most of the reported aspects presented many similarities; only the order of priority differed among them. 
In workshop 6, we discussed the theme of drugs through the touch technique, whose aim was to lead the group to make an association between drugs and the sensations caused by touching the materials presented. Most of the chosen objects represented sensations that had negative connotations: destruction, aggression, lies, addiction, loneliness, violence and fear. However, one teenager reported that the drugs cause many negative effects on a person's life, because they affect a lot of people around them. However, they also provide a good feeling and therefore the user does not think about the harm they do. After this comment, we took time to talk about drugs in general and what effects they have, before winding up the session.

Workshop 7 presented the window of the soul, which aimed to deepen some aspects/perceptions about life, providing the participants with better knowledge to promote rapprochement and interaction. In this technique, the teenagers had to answer questions on various subjects, in order to determine their opinions and tastes. All the young people participated fully by giving their opinions, by complementing the responses of the other participants and by demonstrating sincerity and a lack of inhibitions, even in regard to the most intimate questions.

In the last meeting, we worked on a technique called backpack, whereby the researchers asked the teenagers to reflect on all the meetings. They were asked what they had achieved, about the issues which had been discussed, what they had learned and what these experiences represented for each of them. When socializing, each individual spoke about his/her backpack. It was very interesting, because they talked about the facts in a caring way, highlighting the importance of dialogue, of being able to express their opinions and knowing that they can do something new in the period of dialysis. The thoughts of individuals were often similar to those of the group as a whole. Participants spoke about the techniques worked upon in the meetings. The topics included nostalgia, learning, the importance of the group getting to know each other (and know the authors), the opportunity to do something different with their time, which to them was always a routine and being able to speak and be heard. They reported that they enjoyed the way it was conducted, highlighting the fact that there was something new at every meeting and that it was fun, and therefore not exhausting. They also voiced that the workshops allowed them to demonstrate to others a little of how they feel and what they like.

Regarding the self-assessment of how the adolescents felt before and after the experiential workshops, please refer to Figure 2 below.

Figure 2 - Representation of how the adolescents felt before and after their participation in the experiential workshops. Fortaleza-CE 2012.

\begin{tabular}{ccccccc}
\hline Workshops & \multicolumn{3}{c}{$\begin{array}{l}\text { How am I arriving } \\
\text { (No. of adolescents) }\end{array}$} & \multicolumn{3}{c}{ How am I leaving } \\
(No. of adolescents)
\end{tabular}

In response to the instrument applied at the beginning and end of each workshop, the adolescents had the opportunity to express how they felt at the meetings. After the completion of all the workshops, we found 28 records (44\%) related to the heading "feeling ill, upset and/or sad", 23 (36\%) related to the heading "neither sad nor happy" and 13 (20\%) related to the heading "well, joyful and/or happy" at the beginning of the meetings. The reasons reported for not being well were: sleep, anger, loneliness, fear, 
fights, impatience and fatigue. Adolescents who reported being well said they felt excited, willing and calm.

Regarding the answers as to how they were feeling when they left the meetings (after the workshops), 60 records (94\%) showed that adolescents were "well, joyful and/or happy", 3 (5\%) showed they were "feeling bad, upset and/ or sad "and 1 (1\%) was "indifferent". Those who were well justified this by means of the following words: light, excited, cool, happy, different, attention and important; in relation to feeling bad, angry or upset, they expressed this with the following words: weakness, unwell, malaise, headache, fear and hunger.

Through these records, we identified changes that affected adolescents, as a result of their participation in experiential workshops during the dialysis treatment.

\section{DISCUSSION}

The group activities developed and worked on in the research process sought to evaluate their scope regarding the change in behavior and perspective of humanization of the teenagers, contributing to their well-being through soft technology and revealing the perceived benefits to the study group.

The presentation and approach of the participants was planned, based on different group techniques, which followed pre-established steps for each meeting. This understanding allowed bonding, commitment and humanization to be worked on in all the meetings, and for the experience of care during hemodialysis to be expressed and shared.

The benefits of the experiential workshops for the group included allowing for the close interaction of the participants, the promotion of integration, and working on the humaniza- tion of assistance and allowed for the sharing of perceptions, knowledge and experiences of daily life, as the teenagers expressed their own way of perceiving, feeling and reacting to the issues under discussion. In addition, when listening to different experiences, they reacted positively, encouraged by the dialogue that was established in the group.

At each meeting, we could see greater participation by the adolescents and realized that the techniques favored interaction, disinhibition and initiatives in the development of the proposed activities, as well as improved mood and respect in relation to the responses from colleagues. We also noticed changes in the way they got dressed, personal hygiene and appearance (makeup, painted nails, tidy hair), indicating an improvement in self-esteem.

By using soft technology, it was possible to create a space for the expression of thoughts and feelings, allowing the observation of behavioral changes and the identification of emotional responses, associated with the experience of suffering from chronic renal failure and undergoing hemodialysis.

The choice of approach was based on the potentiating characteristic of group treatment. In this sense, Maximino(9) refers to the "provocative" ability of group activity that produces a middle ground in which the production of this group can materialize in a personal and environmental connection. Thus, the voice, sounds and visual stimuli constitute this materiality.

The practice of nursing care that aims to work with groups and use soft technology is intended to provide a collective construction of the daily life of people with CRF on hemodialysis, questioning their life situations. As a result, it contributes to the mental health and life quality of these individuals, who shift from a secondary position to being protagonists in the care process. The activity requires professional nurses, 
who in this group take on the role of facilitator in the process, to commit to inserting elements in their practices aimed at these goals.

The characteristic of technology in nursing is peculiar, because when taking care of human beings it is not possible to generalize behaviors, but adapt them to different situations, in order to provide individual and appropriate care to people ${ }^{(12,13)}$.

Work in healthcare cannot be expressed based only on the equipment used and on structured technological knowledge, because its more strategic actions represent intervention processes that work as technologies of relationship, of meetings, of subjectivity that go beyond the structured technological knowledge ${ }^{(1415)}$.

In addition to the biological and subjective transformations that are generators of conflicts, adolescence can be even more difficult if it includes a disease such as CRF, which results in many restrictions. Adolescents are more likely to have their mental health affected, compared to healthy individuals. Thus, an adolescent suffering from CRF is more susceptible to psychological distress ${ }^{(16,17)}$.

Reflecting on care with regards to technology makes us think about the inherent ability of human beings to develop innovations that transform their daily lives. In this perspective, nurses should be constantly learning, welcoming new technologies, rethinking their practices and innovating, and have the ability to apply new technological developments to the care process. It's no use having high technology for the development of nursing care, if it does not incorporate humanizing elements, because without them the care becomes fragmented.

Care practices are a challenge for nursing professionals, because each person has values and principles that can influence care. It is necessary to consider that each patient has his/her own way of facing different situations that can be quite stressful. Thus, we analyzed the approach of nursing care professionals, considering the fact that care practices require human relationships, and the fact that hemodialysis nurses rely on the interactive process to conduct this work ${ }^{(18)}$.

Humanizing, in health care, means to understand each person's uniqueness and needs, and thus create conditions for he/she to have more possibilities to exert their will autonomously; it means to treat people differently, taking into account their values and experiences, avoiding any form of negative discrimination, considering their uniqueness, complexity and completeness. Caution, therefore, encompasses acts, behaviors and attitudes ${ }^{(19,20)}$.

In the practice discussed herein, the commitment was related to the transformation of that moment (dialysis) and the impact of the technology used (soft) that might occur within the offered possibilities. This change was made possible from the perception and discussion in terms of the reality, the meeting of new possibilities and the awareness that was raised individually and collectively in the group space.

\section{CONCLUSION}

The use of soft technology has enabled access to new coping resources. Each participant contributed to the discussions, rethought concepts and provided indicative elements to visualize new possibilities for dealing with the difficulties experienced.

This study highlights the experiential workshops, such as soft technology aimed at care, favoring interrelationships, hosting, the production of ties, meetings, subjectivity, working on autonomy and the well-being of those being cared for. 
Despite the scenario of technological equipment (quite characteristic in dialysis clinics) that alleviates the conditions of people with CRF and prolongs their lives, it is necessary to have something more that can impact the various dimensions of the patient. This aspect, in most cases, is neglected or undervalued, since it was observed that there is a gap in the subjective and psychological dimension, and that this can affect the mental health of those involved.

Thus, it is necessary to substantiate the theoretical and practical knowledge related to the demands of the patient dependent on hemodialysis from a systemic vision - hence the importance of using soft technology, such as nursing care, that will provide a better adjustment for adolescents in terms of their condition.

Through this research, it became clear that nursing professionals working in treatment facilities, such as dialysis clinics, can obtain better results in their professional practice if they take into account the various dimensions in terms of the patient and include other technologies in this care.

It is noteworthy, however, that the beneficial effects of the meetings are not restricted or properly connected to the techniques used, but to the possibilities they provide, being an important and rich resource that must be used in the nursing care aimed at adolescents on hemodialysis.

\section{REFERENCES}

1. Leite MF, Gomes IP, Ribeiro KSQS, Anjos UU, Moraes RM, Coller N. Estratégias de enfrentamento de cuidadores de criança com doença crônica: estudo metodológico. Online Brazilian Journal of Nursing. 2013; 12 (2): 238-50.

2. Riella MC. Princípios de nefrologia e distúrbios hidroeletrolíticos. 5 ed. Rio de Janeiro: Guanabara Koogan; 2010.
3. Oliveira APC, Sousa AS, Mendonça AEO, Silva, RAR. Intradialytic complications in patients with chronic renal failure submitted to hemodialysis: integrative review. J Nurs UFPE on line. 2013; 7(spe):6639-45.

4. Marques FA, Legal EJ, Höfelmann DA. Insatisfação corporal e transtornos mentais comuns em adolescentes. Rev paul pediatr. 2012; 30 ( 4 ): 553-61.

5. Beretta LL, Santos MLSC, Fuly PSC, Quintanilha $B M D$, Berardinelii LMM, Aquino JHW. Resilience in adolescents suffering from nom-communicable disease: a crosssectional study. Online Braz J Nurs 2013;12(4): 4481-87.

6. Lorenzini AE. Schaefer AFM. Andrade SDL. Organization of care practices in the health network. Online Braz J Nurs [internet]. 2011 [cited 2013 may 8]; 10(1). Available from: http://www. objnursing.uff.br/index.php/nursing/article/ view/3220

7. Merhy EE. Saúde: a cartografia do trabalho vivo. 2 ed. São Paulo: Hucitec; 2005.

8. Rosso FR, Lima MADS. Acolhimento: tecnologia leve nos processos gerenciais do enfermeiro. Rev Bras Enferm. 2005; 58(3):305-10.

9. Souza AMA. Coordenação de grupos: aspectos técnicos. In: Souza AMA, organizadora. Coordenação de grupos: teoria, prática e pesquisa. Fortaleza: Expressão Gráfica; 2011.

10. Trentini M, Paim L. Pesquisa em enfermagem: uma modalidade convergente-assistencial. Florianópolis: Editora UFSV; 1999.

11. Conselho Nacional de Saúde (Brasil). Comissão Nacional de Ética em Pesquisa - CONESP. Resolução CNS 466 de 12 dezembro de 2012. Diretrizes e normas regulamentadoras de pesquisas envolvendo seres humanos [internet] Diário Oficial [da] União Seção 1, p. 59 [cited 2013 Jul 4]. Available from: http://conselho. saude.gov.br/ resolucoes/2012/Reso466.pdf.

12. Meier MJ. Tecnologia em enfermagem: desenvolvimento de um conceito [tese de doutorado]. Florianópolis (SC): Universidade Federal de Santa Catarina; 2004.

13. Barbosa GS, Valadares Gv. Significando a práxis do enfermeiro de hemodiálise: contribuições ao cuidado de enfermagem - Teoria Fundamentada. Online Braz J Nurs. [internet] 2011 [cited 2014 Nov 10] 10 (2): 3258-62. Available from: http:// 
www.objnursing.uff.br/index.php/nursing/article/view/3258

14. Salvador PTCO, Oliveira RKM, Costa TD, Santos VEP, Tourinho FSV.Technology and innovation for nursing care. Rev. enferm. UERJ, Rio de Janeiro. 2012; 20(1):111-7.

15. Meyer DE. Como conciliar humanização e tecnologia na formação de enfermeiras/os? Rev Bras Enferm. 2002; 55(2):189-95.

16. Ramos IC. Representações sociais dos adolescentes em situação de doença renal crônica sobre o adoecimento e o cuidado [dissertação]. Fortaleza (CE): Universidade Estadual do Ceará; 2007. 138p

17. Ricciardelli L, McCabe MP. Body Image development in adolescent boys. In Cash TF, Smolak L. Body Image: a handbook of science, practice and prevention. New York: Guilford Press; 2011.p. 85-92.

18. Barbosa GS, Valadares GC. Experimentando atitudes e sentimentos: o cotidiano hemodialítico como base para o cuidar em enfermagem. Esc Anna Nery Rev Enferm 2009; 13 (1): 17-23.

19. Waldow Vera Regina, Borges Rosália Figueiró. Cuidar e humanizar: relações e significados. Acta paul. enferm. [internet]. 2011 [cited 2014 Feb 28]; 24( 3 ): 414-418. Available from: http:// www.scielo.br/scielo.php?script=sci_arttext\&pi $\mathrm{d}=$ S010321002011000300017\& ng=en. http:// dx.doi.org/10.1590/S0103-21002011000300017.

20. Bermejo JC. Humanizar a saúde: cuidado, relações e valores. Petrópolis: Vozes; 2008.
All authors participated in the phases of this publication in one or more of the following steps, in According to the recommendations of the International Committee of Medical Journal Editors (ICMJE, 2013): (a) substantial involvement in the planning or preparation of the manuscript or in the collection, analysis or interpretation of data; (b) preparation of the manuscript or conducting critical revision of intellectual content; (c) approval of the versión submitted of this manuscript. All authors declare for the appropriate purposes that the responsibilities related to all aspects of the manuscript submitted to OBJN are yours. They ensure that issues related to the accuracy or integrity of any part of the article were properly investigated and resolved. Therefore, they exempt the OBJN of any participation whatsoever in any imbroglios concerning the content under consideration. All authors declare that they have no conflict of interest of financial or personal nature concerning this manuscript which may influence the writing and/or interpretation of the findings. This statement has been digitally signed by all authors as recommended by the ICMJE, whose model is available in http://www. objnursing.uff.br/normas/DUDE_eng_13-06-2013.pdf
Received: 9/11/2014

Revised: 02/02/2015

Approved: 02/12/2015 